\title{
Transcriptome analysis of the short-term photosynthetic sea slug Placida dendritica
}

\author{
Ji Hee Han ${ }^{1}$, Tatyana A. Klochkova ${ }^{1}$, Jong Won Han ${ }^{2}$, Junbo Shim ${ }^{3}$ and Gwang Hoon Kim ${ }^{1, *}$ \\ ${ }^{1}$ Department of Biology, Kongju National University, Kongju 32588, Korea \\ ${ }^{2}$ National Marine Biodiversity Institute of Korea, Seocheon 33662, Korea \\ ${ }^{3}$ Seaweed Research Center, National Fisheries Research \& Development Institute, Mokpo 58746, Korea
}

\begin{abstract}
The intimate physical interaction between food algae and sacoglossan sea slug is a pertinent system to test the theory that "you are what you eat." Some sacoglossan mollusks ingest and maintain chloroplasts that they acquire from the algae for photosynthesis. The basis of photosynthesis maintenance in these sea slugs was often explained by extensive horizontal gene transfer (HGT) from the food algae to the animal nucleus. Two large-scale expressed sequence tags databases of the green alga Bryopsis plumosa and sea slug Placida dendritica were established using 454 pyrosequencing. Comparison of the transcriptomes showed no possible case of putative HGT, except an actin gene from P. dendritica, designated as PdActin04, which showed 98.9\% identity in DNA sequence with the complementary gene from B. plumosa, BpActin03. Highly conserved homologues of this actin gene were found from related green algae, but not in other photosynthetic sea slugs. Phylogenetic analysis showed incongruence between the gene and known organismal phylogenies of the two species. Our data suggest that HGT is not the primary reason underlying the maintenance of short-term kleptoplastidy in Placida dendritica.
\end{abstract}

Key Words: actin; Bryopsis plumosa; horizontal gene transfer; kleptoplastidy; Placida dendritica; transcriptome

\section{INTRODUCTION}

Photosynthesis in some sacoglossan sea slugs offers a unique model to study the possibility of horizontal gene transfer (HGT) between multicellular predator and prey. Sacoglossan mollusks ingest and actively maintain chloroplasts that they acquire from large coenocytic green algae and keep them for up to several months (Wägele et al. 2011). These kleptoplastidic associations vary greatly in terms of specificity of the animal towards its algal prey and in retention time and functionality of the captured plastids (e.g., Rumpho et al. 2011, Klochkova et al. 2013). The basis for long-term maintenance of photosynthesis in these sea slugs has often been explained by extensive HGT from the nucleus of the alga to the animal nucleus, followed by expression of algal genes in the gut to provide essential plastid-destined proteins (Bhattacharya et al. 2013).

Sacoglossan mollusk Placida dendritica Alder et Hancock is bonded avidly to its specific algal food Bryopsis spp. (Klochkova et al. 2010). When it develops from a veliger larva to a small animal, at final stage of metamorphosis it attaches to and consumes only Bryopsis plants for the rest of its life cycle. In north Atlantic waters, $P$.
(9) $\$$ This is an Open Access article distributed under the terms of the Creative Commons Attribution Non-Commercial License (http://creativecommons.org/licenses/by-nc/3.0/) which permits unrestricted non-commercial use, distribution, and reproduction in any medium, provided the original work is properly cited.
Received June 18, 2015, Accepted October 29, 2015

* Corresponding Author

E-mail: ghkim@kongju.ac.kr

Tel: +82-41-850-8504, Fax: +82-41-850-8479 


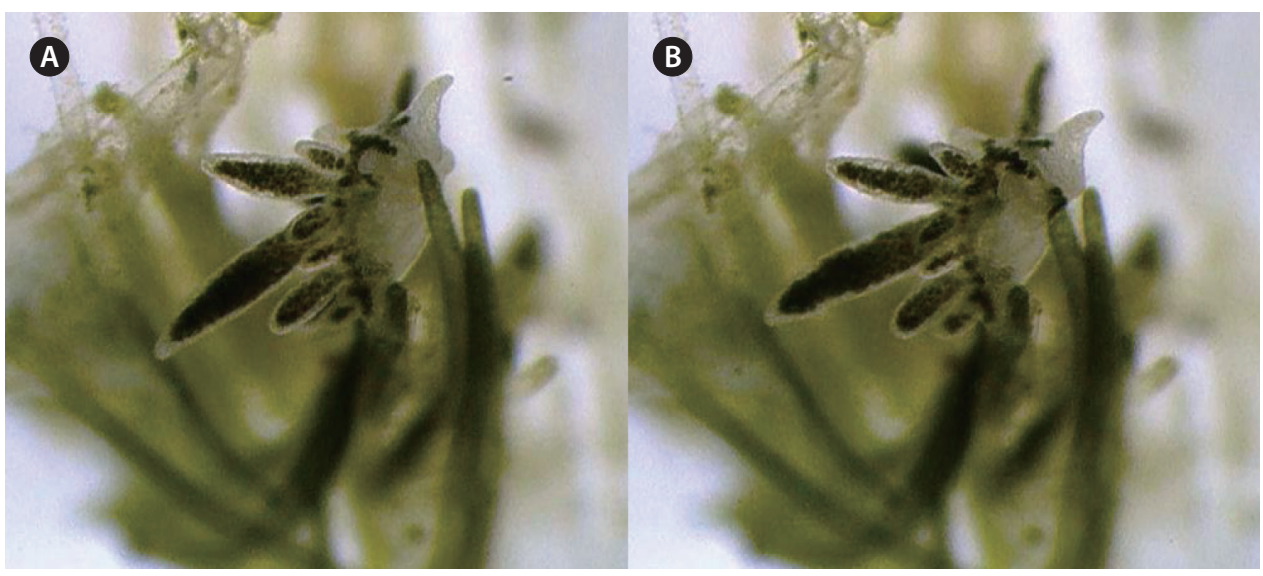

Fig. 1. Feeding of Placida dendritica on the protoplasm of Bryopsis plumosa. (A) Sea slug attached to B. plumosa filament and punctured its cell with sharp radula. (B) A fine stream of algal protoplasm is seen through the transparent head of sea slug, entering its digestive system as it feeds.

dendritica is commonly found associated with Codium fragile (Suringar) Hariot (Evertsen and Johnsen 2009), but most Korean samples were collected on Bryopsis spp. In laboratory culture with mixed diet algae, the animals consumed only Bryopsis spp. and less than 10\% of them switched to Codium minus (Schmidt) Silva or Derbesia tenuissima (Moris et De Notaris) P. L. Crouan et H. M. Crouan, even when no Bryopsis was available (Klochkova et al. 2010). Chloroplasts were observed in the digestive tract of P. dendritica and were found to be functional for a short time (Klochkova et al. 2010).

In this study, we present initial results from the comparative analysis of transcriptomes of $P$. dendritica and its food alga B. plumosa that suggest the maintenance of photosynthesis in the sea slug is not directly related with the horizontally transferred genes from algae. However, possible case of putative HGT was found, such as an actin gene from P. dendritica.

\section{MATERIALS AND METHODS}

Adult animals of $P$. dendritica (Fig. 1) were collected from Wando, southern coast of Korea $\left(34^{\circ} 19^{\prime} 37.32^{\prime \prime} \mathrm{N}\right.$, $120^{\circ} 48^{\prime} 43.55^{\prime \prime}$ E). Collected sea slugs were washed with filtered artificial seawater and kept in marine IMR medium at $15^{\circ} \mathrm{C}$ with $12: 12 \mathrm{~h} \mathrm{~L}: \mathrm{D}$ cycle and $15 \mu \mathrm{mol} \mathrm{m}^{-2} \mathrm{~s}^{-1}$ light intensity and without food.

For transcriptome analysis, sea slugs were kept without any food algae (i.e., starved) for 28 days and the Petri dish with culture medium was changed every day. Egg ribbons were harvested from one week after starvation, when no chloroplasts remained in the digestive tract of the sea slugs, because defecation stopped by that time and their body color was turning yellowish by each passing day. The harvested eggs were rinsed with $3 \% \mathrm{H}_{2} \mathrm{O}_{2}$, frozen in liquid nitrogen and kept in deep freezer $\left(-70^{\circ} \mathrm{C}\right)$ until use. Other sacoglossan sea slugs, Elysia atroviridis Baba and Elysia nigrocapitata Baba, were collected from the same locality. The animals were maintained using same method as for P. dendritica.

All algae (Appendix 1) were cultured in marine IMR medium at $20^{\circ} \mathrm{C}$ with $12: 12 \mathrm{~h} \mathrm{~L}$ : D cycle and $15 \mu \mathrm{mol} \mathrm{m}^{-2}$ $\mathrm{s}^{-1}$ light intensity.

\section{Isolation of total RNA and mRNA purification}

Total RNA from B. plumosa and P. dendritica was isolated using Trizol (MRC Inc., Cincinnati, OH, USA) according to manufacturer's protocol. Thirty animals of $P$. dendritica, which had been starved for 28 days, were used. Isolated RNA was quantified spectrophotomertically $(260$ and $280 \mathrm{~nm}$ ). mRNA was purified using Oligotex (Qiagen, Valencia, CA, USA) following manufacturer's instructions. Double-strand cDNA was synthesized using Just cDNA Double-stranded cDNA Synthesis Kit (Agilent Technologies, Palo Alto, CA, USA) following manufacturer's instructions. The cDNA was then sent to Macrogen (http:// www.macrogen.com/eng/) for 454 pyrosequencing. The library preparation, GS-FLX titanium sequencing, assembly and annotation of sequencing data were carried out by Macrogen (Appendix 2). To analyze the sequence data a web-based pipeline program for expressed sequence tag (EST) data analysis was established (http://genebank2.kongju.ac.kr). 


\section{Genomic DNA isolation, polymerase chain reac- tion (PCR) and sequence determination}

DNA was purified from algal samples from different localities (Appendix 1) and the eggs of sea slugs using Intron i-genomic plant DNA extraction mini kit or CTAB DNA extraction mini kit (Intron Biotechnology, Seoul, Korea) following the manufacturer's instructions. Isolated DNA was diluted to $10 \mathrm{ng} \mu \mathrm{L}^{-1}$ of concentration and directly used to PCR reaction. Specific primers were designed based on pyrosequencing database (Appendix 3). PCR was performed as follows: an initial denaturation at $95^{\circ} \mathrm{C}$ for $4 \mathrm{~min}$, followed by 35 cycles of amplification (denaturation at $94^{\circ} \mathrm{C}$ for $30 \mathrm{~s}$, annealing at $55^{\circ} \mathrm{C}$ for $40 \mathrm{~s}$, and extension at $72^{\circ} \mathrm{C}$ for $1.5 \mathrm{~min}$ ) with a final extension at $72^{\circ} \mathrm{C}$ for $10 \mathrm{~min}$.

\section{Bioinformatics}

Transcriptome of B. plumosa was compared with that of $P$. dendritica by local blast program based on nucleotide sequence (BlastN) from BioEdit ver. 7.0 (Ibis Therapeutics, Carlsbad, CA, USA). All the contigs and singletons of the two species were compared and a table of similar genes was generated. The contigs and singleton sequences smaller than $200 \mathrm{bp}$ were removed from the data set. BlastN parameters were set to expectation value $>1.0 \mathrm{e}^{-60}$ and identity $>85 \%$ using BLOSUM62 matrix. Genes were selected by keyword searches from the final spreadsheets obtained from the above annotation process. Functional annotation was used to obtain matches with the following terms: photosynthesis, chlorophyll, light harvesting, intracellular transport, metabolic processes (carbohydrates, lipids, and proteins), organelle organization and biogenesis. Additional homology searches were conducted by comparing our translated EST database directly with the comprehensive chloroplast protein database of Arabidopsis thaliana (plastid protein database: http:// www.plprot.ethz.ch and AT-Chloro database: http:// www.grenoble.prabi.fr/at_chloro) with a cut-off E-value of $\mathrm{e}^{-50}$ (Kleffmann et al. 2004). The BioEdit sequence alignment editor program (ver. 7.2.3) was used for sequence homology analysis. An EST database of Dictyostelium discoideum Raper obtained from NCBI EST database (dbEST ID: 13952321) was compared with the assembly results of B. plumosa using the method described above. As there were no significant matches at the BlastN parameters above, the parameters were lowered to expectation value $>1.0 \mathrm{e}^{-20}$ and identity $>75 \%$ using BLOSUM62 matrix.

\section{Phylogenetic analysis}

The actin sequences examined in this study were aligned with the actin sequences from GenBank using MacClade 4.08. The nucleotide alignment contained 65 sequences and was trimmed to 778 nucleotide comparable positions without third codon position using Paup*v. b10. Maximum likelihood analysis was performed using RAxML 7.0.4 with rapid bootstrapping option and 1,000 replicates under GTR $+\mathrm{I}+\Gamma$ model. Tree was visualized and graphic versions were exported using FigTree v1.4.0. New actin sequences generated in this study have been deposited in NCBI under the accession numbers listed in Appendix 4. Accession numbers for the sequences from NCBI used to construct phylogenetic tree are listed in Appendix 5 .

\section{RESULTS AND DISCUSSION}

Functional annotation on $P$. dendritica transcriptome showed no putative gene related to the following terms: light and dark reaction of photosynthesis, chlorophyll assimilation, and light harvesting complex. Additional homology searches comparing $P$. dendritica transcriptome with the comprehensive chloroplast protein database of A. thaliana (Kleffmann et al. 2004) showed no significant match, except for some ribosomal genes with a cut-off Evalue of $\mathrm{e}^{-50}$.

Comparison of two large-scale ESTs databases of $B$. plumosa and $P$. dendritica showed few candidates of putative HGT except an actin homologue (Table 1). Nine actin homologues were isolated from $P$. dendritica EST database and three from B. plumosa (Table 2). One actin homologue from $P$. dendritica, designated as PdActin04, showed $98.9 \%$ identity in DNA sequence with the complementary gene from B. plumosa, BpActin03, while all the other genes, including other actin homologues, ribosomal proteins, and tubulin genes of the two species showed much lower similarity ( $\leq 86 \%$ ) (Table 1 ). Full sequence of PdActin04 was obtained from genomic PCR using the egg cells of $P$. dendritica. Highly conserved homologues (93$99 \%$ of DNA sequence identity) of this gene were found in eight other ulvophyceaen algae (Appendix 6). However, PdActin04 homologue was not found in the eggs of other related sacoglossan species (Elysia atroviridis, E. nigrocapitata), which also feed on Bryopsis spp. The sequence difference between BpActin03 and PdActin04 was similar to that between species of Bryopsis. Most DNA substitution among BpActin03 homologues of ulvophyceaen 
algae were synonymous; the translated amino acid sequences were almost identical $(>99.7 \%)$ to each other. It is noteworthy that three DNA substitutions occurring in PdActin04 were not synonymous and not observed in any other green algae (Fig. 2).

Phylogenetic analysis showed incongruence between the actin gene and known organismal phylogenies of the animals and algae (Fig. 3). Surprisingly, all BpActin03

Table 1. Results of BLAST analysis between the transcriptomes of Bryopsis plumosa and Placida dendritica

\begin{tabular}{|c|c|c|c|c|c|c|c|}
\hline $\begin{array}{l}\text { B. plumosa } \\
\text { unigene No. }\end{array}$ & $\begin{array}{l}\text { P.dendritica } \\
\text { unigene No. }\end{array}$ & $\begin{array}{l}\text { Identity } \\
(\%)\end{array}$ & $\begin{array}{c}\text { Aligned } \\
\text { length (nt) }\end{array}$ & $\begin{array}{l}\text { No. of different } \\
\text { nucleotides }\end{array}$ & Gap & E-value & $\begin{array}{c}\text { Candidate gene / } \\
\text { Organism }\end{array}$ \\
\hline Contig03964 & GKI0DVN02FWMUH & 98.91 & 460 & 2 & 3 & 0.0 & Actin / Vannella ebro \\
\hline GG4S1ZQ01BMRNG & GKI0DVN02F5TO3 & 86.36 & 396 & 54 & 0 & $3.00 \mathrm{E}-97$ & $\begin{array}{l}\text { Tubulin alpha subunit / } \\
\text { Monocercomonoides sp. }\end{array}$ \\
\hline GG4S1ZQ01DCBGZ & GKI0DVN02IJE3H & 84.75 & 459 & 67 & 3 & $4.00 \mathrm{E}-90$ & Beta tubulin / Bicosoecida sp. \\
\hline GG4S1ZQ01A4RL0 & GKI0DVN02HT1UO & 85.86 & 382 & 52 & 2 & $4.00 \mathrm{E}-84$ & Beta tubulin / Bicosoecida sp. \\
\hline GG4S1ZQ01DRYND & GKI0DVN02HT1UO & 85.86 & 382 & 52 & 2 & $4.00 \mathrm{E}-84$ & Beta tubulin / Bicosoecida sp. \\
\hline GG4S1ZQ01ANI4F & GKI0DVN02JFK1H & 86.13 & 346 & 48 & 0 & $2.00 \mathrm{E}-82$ & Beta actin / Lates calcarifer \\
\hline Contig02740 & GKI0DVN02GALET & 86.88 & 320 & 42 & 0 & $2.00 \mathrm{E}-80$ & Ribosomal protein L4 \\
\hline Contig05555 & GKI0DVN02HLG12 & 82.82 & 483 & 81 & 2 & $2.00 \mathrm{E}-74$ & $\begin{array}{l}\text { 40S ribosomal protein } \mathrm{S} 15 \text { / } \\
\text { Zea mays }\end{array}$ \\
\hline Contig06211 & GKI0DVN02ITH6G & 81.89 & 486 & 88 & 0 & $8.00 \mathrm{E}-70$ & $\begin{array}{l}\text { Tubulin alpha chain / } \\
\text { Micromonas pusilla }\end{array}$ \\
\hline Contig01502 & GKI0DVN02INZTJ & 82.77 & 412 & 70 & 1 & $8.00 \mathrm{E}-64$ & $\begin{array}{l}\text { Alpha tubulin } 2 \text { / } \\
\text { Micromonas sp. }\end{array}$ \\
\hline
\end{tabular}

Genes are listed in the order of highest sequence identity.

Table 2. Actin homologues from Placida dendritica and Bryopsis plumosa

\begin{tabular}{|c|c|c|c|c|c|}
\hline & Unigene No. & E-value & Species (BlastN) & E-value & Species (BlastX) \\
\hline \multicolumn{6}{|c|}{ Placida dendritica } \\
\hline PdActin01 & PdContig08492 & 0.0 & $\begin{array}{l}\text { Aplysia californica } \\
\text { (X52868) }\end{array}$ & $6 e-176$ & $\begin{array}{l}\text { Mizuhopecten yessoensis } \\
\text { (Q26065) }\end{array}$ \\
\hline PdActin02 & PdContig22473 & $8 e-122$ & $\begin{array}{l}\text { Urechis unicinctus } \\
\text { (GU592178) }\end{array}$ & $4 e-58$ & $\begin{array}{l}\text { Molgula oculata } \\
\text { (AAC28358) }\end{array}$ \\
\hline PdActin03 & Pdcontig23501 & 0.0 & $\begin{array}{r}\text { Elysia timida } \\
\text { (HP148203) }\end{array}$ & $3 e-145$ & $\begin{array}{l}\text { Hippoglossus hippoglossus } \\
\text { (ACZ63697) }\end{array}$ \\
\hline \multirow[t]{2}{*}{ PdActin04 } & PdGKI0DVN02FWMUH & $5 e-174$ & $\begin{array}{l}\text { Pyrocystis lunula } \\
\text { (AF508263) }\end{array}$ & $1 e-71$ & $\begin{array}{l}\text { Vannella ebro } \\
\text { (AAQ55798) }\end{array}$ \\
\hline & & & $\begin{array}{l}\text { Vannella ebro } \\
\text { (AY294151) }\end{array}$ & & \\
\hline PdActin05 & PdGKI0DVN02HC94M & 0.0 & $\begin{array}{l}\text { Aplysia californica } \\
\text { (EZ114794) }\end{array}$ & $3 e-48$ & $\begin{array}{l}\text { Hyriopsis cumingii } \\
\text { (ADG26659) }\end{array}$ \\
\hline PdActin06 & PdGKI0DVN02F6MNO & $1 e-75$ & $\begin{array}{l}\text { Hypsibius klebelsbergi } \\
\text { (HM238268) }\end{array}$ & $4 e-87$ & $\begin{array}{l}\text { Gromia oviformis } \\
\text { (AAT42195) }\end{array}$ \\
\hline PdActin07 & PdGKI0DVN02H3D9W & e-100 & $\begin{array}{l}\text { Rhizamoeba sp. } \\
\text { (EU273459) }\end{array}$ & $3 e-43$ & $\begin{array}{l}\text { Rhizamoeba sp. } \\
\text { (ACA04833) }\end{array}$ \\
\hline PdActin08 & Pdcontig03862 & $2 \mathrm{e}-15$ & $\begin{array}{r}\text { Elysia timida } \\
(\mathrm{HP} 141184)\end{array}$ & $5 e-25$ & $\begin{array}{l}\text { Gallus gallus } \\
\text { (AAA48570) }\end{array}$ \\
\hline PdActin09 & Pdcontig14953 & 0.0 & $\begin{array}{l}\text { Placobranchus ocellatus } \\
\text { (HP176466) }\end{array}$ & $6 e-108$ & $\begin{array}{l}\text { Biomphalaria glabrata } \\
\text { (AAN31639) }\end{array}$ \\
\hline \multicolumn{6}{|c|}{ Bryopsis plumosa } \\
\hline BpActin 01 & Bpcontig00392 & $1 e-149$ & $\begin{array}{r}\text { Oryza sativa } \\
\text { (CT831215) }\end{array}$ & $3 e-168$ & $\begin{array}{l}\text { Chlamydomonas reinhardtii } \\
\text { (XP001699068) }\end{array}$ \\
\hline BpActin 02 & Bpcontig4636 & $3 e-37$ & $\begin{array}{l}\text { Candida glabrata } \\
\text { (FN394021) }\end{array}$ & 3e-161 & $\begin{array}{l}\text { Nannochloris bacillaris } \\
\text { (BAA25911) }\end{array}$ \\
\hline \multirow[t]{2}{*}{ BpActin 03} & Bpcontig3964 & 0.0 & $\begin{array}{l}\text { Pyrocysitis lunula } \\
\text { (AF508263) }\end{array}$ & 0.0 & $\begin{array}{l}\text { Vannella ebro } \\
\text { (AAQ55798) }\end{array}$ \\
\hline & & & $\begin{array}{l}\text { Vannella ebro } \\
\text { (AY294151) }\end{array}$ & & \\
\hline
\end{tabular}




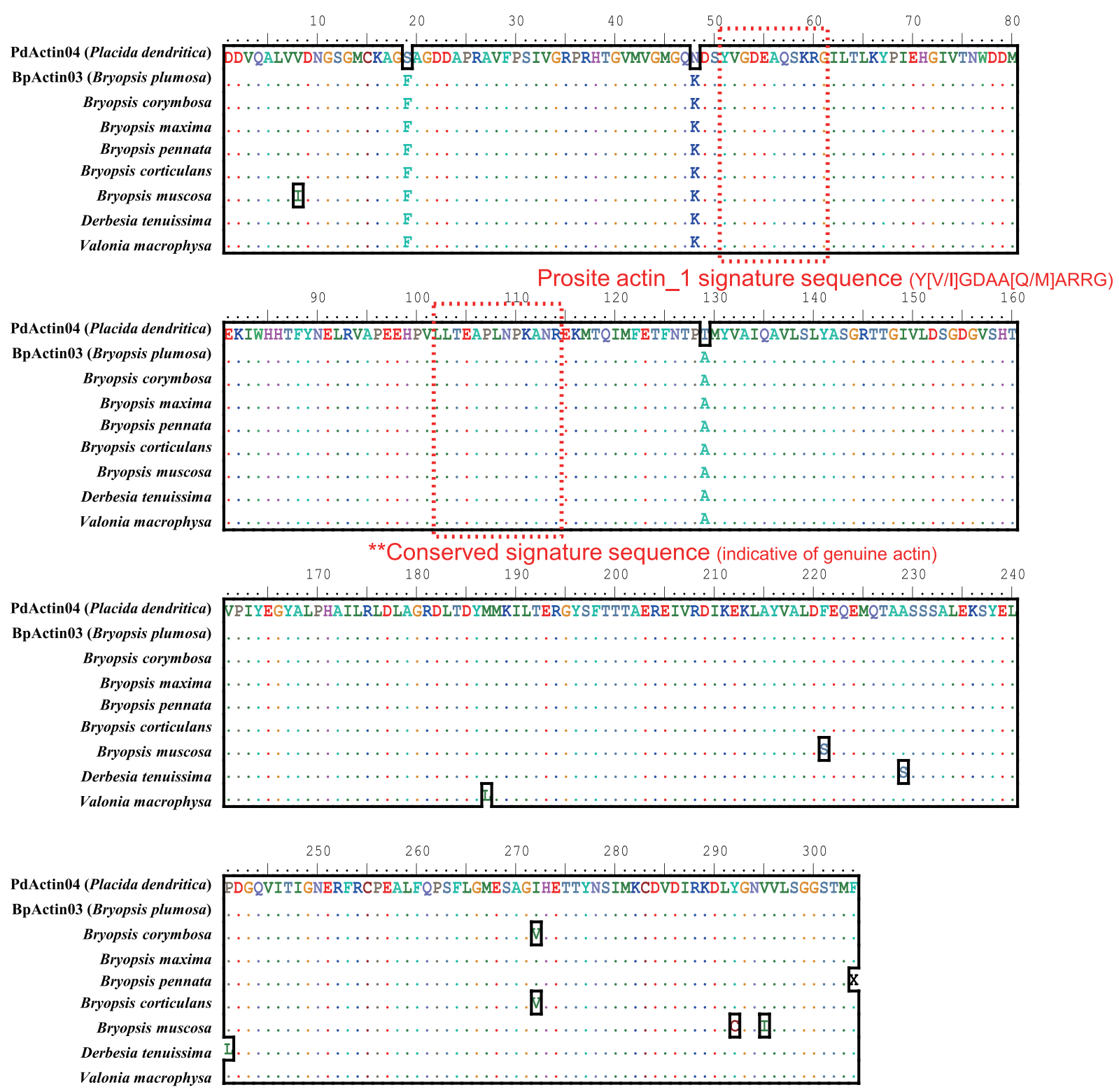

Fig. 2. Aligned amino acid sequence of BpActin03 and homologues isolated from Placida dendritica and ulvophyceaen green algae. Signature sequences of actin are marked in the dashed boxes.

Table 3. Results of BLAST analysis between the transcriptomes of Bryopsis plumosa and Dictyostelium discoideum

\begin{tabular}{llcccccl}
\hline B.plumosa & D. discoideum & Identity (\%) & $\begin{array}{c}\text { Aligned length } \\
\text { (nt) }\end{array}$ & $\begin{array}{c}\text { No. of different } \\
\text { nucleotides }\end{array}$ & Gap & E-value & Candidate gene \\
\hline Contig03964 & AU284282 & 87.51 & 1,121 & 140 & 0 & 0 & Actin \\
Contig00173 & AU034477 & 78.42 & 329 & 71 & 0 & $5.00 \mathrm{E}-17$ & 26S proteasome ATPase 2 subunit \\
Contig07345 & AU284686 & 83.23 & 310 & 50 & 2 & $2.00 \mathrm{E}-46$ & Rho GTPase \\
Contig00066 & C92100 & 79.7 & 266 & 54 & 0 & $4.00 \mathrm{E}-20$ & Cyclophilin B \\
Contig06145 & C24683 & 85 & 260 & 37 & 2 & $2.00 \mathrm{E}-47$ & ADP-ribosylation factor \\
Contig03691 & C92100 & 81.75 & 252 & 46 & 0 & $7.00 \mathrm{E}-31$ & Cyclophilin B \\
Contig06316 & AU034961 & 87.76 & 245 & 28 & 2 & $4.00 \mathrm{E}-60$ & Ras GTPase \\
\hline
\end{tabular}

Genes are listed in the order of highest sequence homology. 


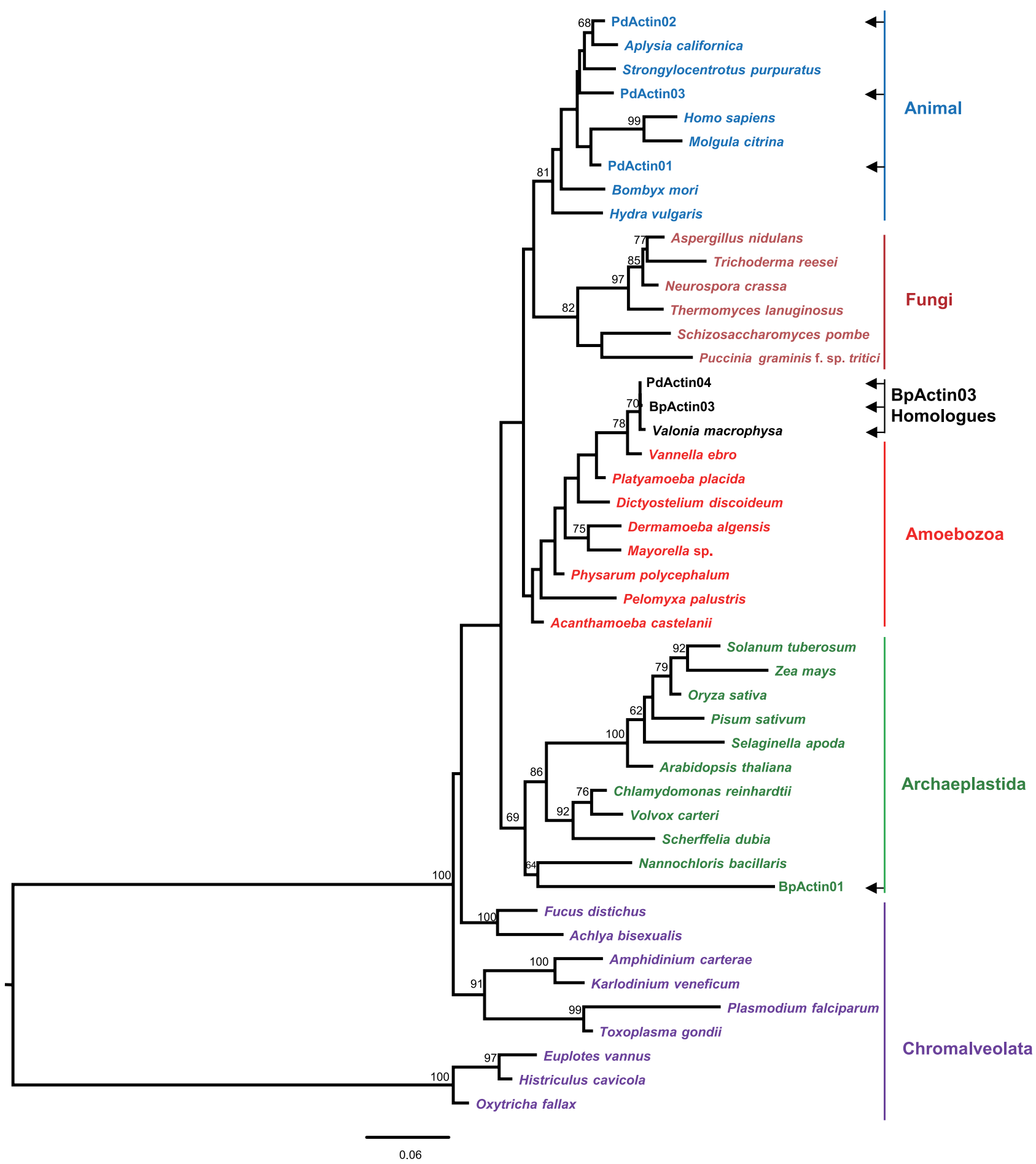

Fig. 3. Phylogenetic analysis of the first and second codon positions ( $778 \mathrm{nt})$ of actin genes. This tree was identified with maximum-likelihood method and has been out-rooted with ciliate actin sequences. The bootstrap values (1,000 replicates) are shown above nodes. Only the values over $60 \%$ are shown. Arrows show the actin genes detected in this study. 
homologues were grouped within a branch of Amoebozoa, while other actin genes from the two species were grouped appropriately in the Archaeplastida and Opisthokonta (Fig. 3). To check if PdActin04 homologues are from simultaneous contamination of some Amoebozoa species, the transcriptomes of P. dendritica and B. plumosa were compared with that of an amoeba $D$. discoide$u m$. No genes from two EST databases showed significant homology with that of $D$. discoideum (Table 3 ).

Our results did not show any photosynthesis-related genes in P. dendritica transcriptome, which suggest that HGT may not be the primary reason underlying the maintenance of photosynthesis in this mollusk. To become an active nuclear-encoded functional chloroplast protein and return to the plastid, the transferred gene must be assimilated into the host nuclear genome, acquire a transit sequence for targeting the protein to the organelle and be transcribed and processed back into the chloroplast (Bhattacharya et al. 2013). It would be less surprising that a common cytosolic gene like actin which may not require all the steps described above has been successfully transferred and transcribed between two intimately associated organisms. The specialized feeding and use of algal organelles by the sacoglossan mollusks also support the possibility of HGT among them.

The gold standard for identifying HGT with confidence is phylogenetic incongruence and this occurs if there is strong conflict between the phylogenies of the gene and of the organism (Keeling and Palmer 2008). The incongruence between the gene and known organismal phylogenies of the herbivore and algae did not support that PdActin04 has been horizontally transferred from its food algae. PdActin04 and all of its homologues found in green algae were nested in a branch of the Amoebozoa phylogeny (Fig. 3). It is possible that BpActin03 homologues are from a common amoeba contaminating all algal strains as well as the sea slugs simultaneously. If the contamination was from laboratory culture, all BpActin03 homologues should have the same sequence.

However, DNA sequences of nine BpActin03 homologues were clearly different among species. It means there must be nine different amoebas specifically contaminating algal strains, as well as the sea slug. It is hard to believe that each algal strain, collected from different localities of the world in different times, carry a specific amoeba and never mixed during years of laboratory culture. Most of all, the sequence difference among the homologues reflected the phylogenetic distance among ulvophyceaen algae; species closely related showed less sequence difference (Appendix 6). DNA sequence homology among BpActin03 homologues ranged 93-99\%.

Direct comparison of large EST databases enabled us to avoid a long-lasting concern with HGT studies, that of contamination of targeted genes. If the materials used for building EST database of $P$. dendritica were contaminated with $B$. plumosa the transcriptomes of the two species would share many genes in common. Simultaneous contamination of the two EST databases by a common amoeba would also reveal more genes in common between B. plumosa and P. dendritica, not just one actin gene. Although all these evidences indicate that BpActin03 homologues are not from a contaminating amoeba, the questions about how and when this actin gene transferred to green algal lineage still remains.

\section{CONCLUSION}

The intimate physical interaction between herbivore and food algae may lead to horizontal transfer of certain genes. The short-term kleptoplastidy occurring in Placida dendritica does not seem to be based on any genetic incorporation from the food algae, Bryopsis spp. An interesting actin lineage was found and gene was isolated as a candidate of putative HGT between them, but the incongruence between the gene and known organismal phylogenies did not support the possibility of HGT. Highly conserved actin gene lineage found in this study may be useful in interpreting the evolutionary relationship among higher level of taxa.

\section{ACKNOWLEDGEMENTS}

This research was supported by Golden Seed Project, Ministry of Agriculture, Food and Rural Affairs (MAFRA), Ministry of Oceans and Fisheries (MOF), Rural Development Administration (RDA) and Korea Forest Service (KFS). This research was also a part of the project titled 'Development of selection techniques of suitable industrial variety in Korean coast', funded by the Ministry of Oceans and Fisheries, Korea. This research was also partially covered by Kongju National University grant to GHK for sabbatical year. Authors express sincere thanks to Dr. G. C. Zuccarello for his critical and very helpful comments regarding phylogenetic results. We also thank Dr. J. A. West for loaning two algal strains used in this study. 


\section{REFERENCES}

Bhattacharya, D., Pelletreau, K. N., Price, D. C., Sarver, K. E. \& Rumpho, M. E. 2013. Genome analysis of Elysia chlorotica egg DNA provides no evidence for horizontal gene transfer into the germ line of this kleptoplastic mollusc. Mol. Biol. Evol. 30:1843-1852.

Evertsen, J. \& Johnsen, G. 2009. In vivo and in vitro differences in chloroplast functionality in the two north Atlantic sacoglossans (Gastropoda, Opisthobranchia) Placida dendritica and Elysia viridis. Mar. Biol. 156:847-859.

Keeling, P. J. \& Palmer, J. D. 2008. Horizontal gene transfer in eukaryotic evolution. Nat. Rev. Genet. 9:605-618.

Kleffmann, T., Russenberger, D., von Zychlinski, A., Christopher, W., Sjölander, K., Gruissem, W. \& Baginsky, S. 2004. The Arabidopsis thaliana chloroplast proteome reveals pathway abundance and novel protein functions. Curr. Biol. 14:354-362.
Klochkova, T. A., Han, J. W., Chah, K. -H., Kim, R. W., Kim, J. -H., Kim, K. Y. \& Kim, G. H. 2013. Morphology, molecular phylogeny and photosynthetic activity of the sacoglossan mollusc, Elysia nigrocapitata, from Korea. Mar. Biol. 160:155-168

Klochkova, T. A., Han, J. W., Kim, J. -H., Kim, K. Y. \& Kim, G. H. 2010. Feeding specificity and photosynthetic activity of Korean sacoglossan mollusks. Algae 25:217-227.

Rumpho, M. E., Pelletreau, K. N., Moustafa, A. \& Bhattacharya, D. 2011. The making of a photosynthetic animal. J. Exp. Bot. 214:303-311.

Wägele, H., Deusch, O., Händeler, K., Martin, R., Schmitt, V., Christa, G., Pinzger, B., Gould, S. B., Dagan, T., Klussmann-Kolb, A. \& Martin, W. 2011. Transcriptomic evidence that longevity of acquired plastids in the photosynthetic slugs Elysia timida and Plakobranchus ocellatus does not entail lateral transfer of algal nuclear genes. Mol. Biol. Evol. 28:699-706.

Appendix 1. List of unialgal strains used in this study and information on their collection site or source

\begin{tabular}{|c|c|}
\hline Species & Collection locality, date, collector \\
\hline Bryopsis corticulans & Gangneung, Korea; Nov 7, 2007; Coll.: Klochkova, T. A. \\
\hline Bryopsis corymbosa & Peter the Great Bay, Japan Sea, Russia; Sep 2003; Coll.: Klochkova, T. A. \\
\hline Bryopsis maxima & Wando, Chondori, Korea; Feb 2008; Coll.: Klochkova, T. A. \\
\hline Bryopsis muscosa & Gangneung, Korea; Nov 7, 2007; Coll.: Klochkova, T. A. \\
\hline Bryopsis pennata & Jeju Island, Korea; Oct 19, 2007; Coll.: Klochkova, T. A. \\
\hline Bryopsis plumosa & Kacheon, Korea; Apr 2003; Coll.: Klochkova, T. A. \\
\hline Derbesia tenuissima (No. 4303, sporophyte) ${ }^{\mathrm{a}}$ & White Beach, Batanes Prov. Philippines; Apr 1987 \\
\hline Valonia macrophysa (No. 1528) ${ }^{\mathrm{a}}$ & Gran Comoro Islands; Mar 1975 \\
\hline
\end{tabular}

${ }^{a}$ Strains obtained from culture collection of J. A. West.

Appendix 2. Overview of 454 pyrosequencing and assembly results

\begin{tabular}{lrr}
\multicolumn{1}{c}{ Characteristics } & Bryopsis plumosa & Placida dendritica \\
\hline Total number of reads & 396,752 & 567,033 \\
Total number of bases (bp) & $158,414,036$ & $247,212,265$ \\
Assembled reads & 330,192 & 180,409 \\
Singletons & 25,403 & 98,858 \\
Repeat (reads) & 326 & 164,025 \\
Contigs number (length $\geq 500 \mathrm{bp})$ & 5,710 & 8,656 \\
Bases (contigs) & $5,215,088$ & $6,962,221$ \\
Average contig size & 913 & 804 \\
\hline
\end{tabular}


Appendix 3. Primers used for polymerase chain reaction in Bryopsis plumosa actin gene study

\begin{tabular}{clll}
\hline Actin name (UniGene No.) & Primer name & Direction & \multicolumn{1}{c}{ Sequences } \\
\hline BpActin01 (Bpcontig 392) & BP_392F_1 & Forward & CCTGAACCCAAGAACCATTGCTGCT \\
& BP_392SF_2 & Forward & ACGAGGCCGAGCTCCTCAAGT \\
& BP_392R_1 & Reverse & CCTCATCATCCTTTCCGATGAGAG \\
& BP_392SR_2 & Reverse & GGAGTTGTAAGTGGTGCCAGT \\
BpActin02 (Bpcontig 4636) & BP_4636F_1 & Forward & AGCGTCGACTTCGGAACGGAGG \\
& BP_4636R_1 & Reverse & GGCAGAAACCTGCTTGTGCGA \\
BpActin03 (Bpcontig 3694) & BP_3694F_12 & Forward & ACGATGATGTTCAAGCTCTTGT \\
& BP_3694SF_1 & Forward & ATGAACTTAGAGTTGCTCCAG \\
& BP_3694R_905 & Reverse & GGAACATAGTTGATCCACCGGA \\
\hline
\end{tabular}

Appendix 4. NCBI accession numbers for the sequences newly generated in this study

\begin{tabular}{lcc}
\hline \multicolumn{1}{c}{ Organism } & Designated actin strain name & GenBank accession No. \\
\hline Bryopsis corticulans & BcorActin01 & KT950951 \\
Bryopsis corymbosa & BcoryActin01 & KT950952 \\
Bryopsis maxima & BmaxActin01 & KT950953 \\
Bryopsis muscosa & BmusActin01 & KT950954 \\
Bryopsis pennata & BpenActin01 & KT950950 \\
Bryopsis plumosa & BpActin01 & KT950948 \\
& BpActin03 & KT950949 \\
Derbesia tenuissima $\left(\right.$ No. 4303, sporophyte) ${ }^{\mathrm{a}}$ & DtActin01 & KT950955 \\
Valonia macrophysa $\left(\right.$ No. 1528) ${ }^{\mathrm{a}}$ & ValActin01 & KT950956 \\
Placida dendritica & PdActin01 & KT950957 \\
& PdActin02 & KT950958 \\
\end{tabular}

${ }^{\mathrm{a}}$ Strains obtained from culture collection of J. A. West.

Appendix 5. NCBI accession numbers for the sequences used to construct phylogenetic tree in this study

\begin{tabular}{|c|c|}
\hline \multicolumn{2}{|c|}{ Organism (GenBank accession No.) } \\
\hline Acanthamoeba castelanii (V00002) & Oryza sativa (AC092557) \\
\hline Achlya bisexualis (X59936) & Oxytricha fallax (U63567) \\
\hline Amphidinium carterae (EU742738) & Pelomyxa palustris (AY294156) \\
\hline Aplysia californica (U01352) & Physarum polycephalum (M21501) \\
\hline Arabidopsis thaliana (U39449) & Pisum sativum (U76190) \\
\hline Aspergillus nidulans (XM_659054) & Plasmodium falciparum (M22719) \\
\hline Bombyx mori (NM_001126253) & Platyamoeba placida (AY294153) \\
\hline Chlamydomonas reinhardtii (D50839) & Puccinia graminis f. sp. tritici (XP_003323586) \\
\hline Dermamoeba algensis (AY294159) & Scherffelia dubia (AF061018) \\
\hline Dictyostelium discoideum (M14146) & Schizosaccharomyces pombe (D84318) \\
\hline Euplotes vannus (AF273753) & Selaginella apoda (AF090969) \\
\hline Fucus distichus (U11697) & Solanum tuberosum (X55752) \\
\hline Histriculus cavicola (Y12047) & Strongylocentrotus purpuratus (J01202) \\
\hline Homo sapiens (BC012597) & Thermomyces lanuginosus (X07463) \\
\hline Hydra vulgaris (M32364) & Toxoplasma gondii (U10429) \\
\hline Karlodinium veneficum (GQ152584) & Trichoderma reesei (CAA53173) \\
\hline Mayorella sp. (AY294152) & Vannella ebro (AY294151) \\
\hline Molgula citrina (L21915) & Volvox carteri (M33963) \\
\hline Nannochloris bacillaris (AB013098) & Zea mays (J01238) \\
\hline Neurospora crassa (XM_956040) & \\
\hline
\end{tabular}


Appendix 6. Aligned DNA sequence of BpActin03 and homologues isolated from Placida dendritica and ulvophyceaen green algae

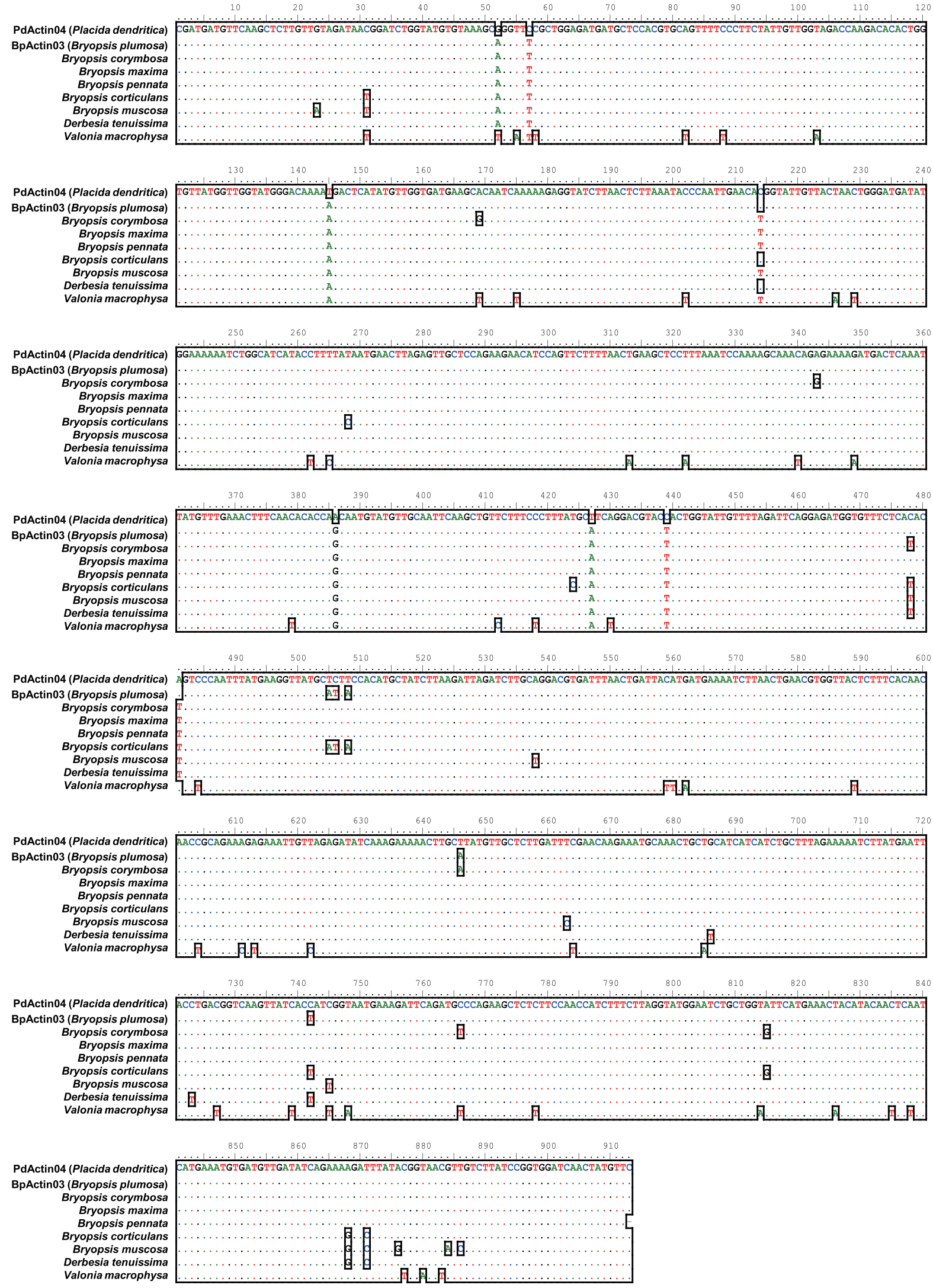

